\title{
Use of I in Essays by Japanese EFL Learners
}

\section{Sayo Natsukari Rikkyo University}

A problematic issue in Japanese EFL learners' academic writing is the overuse of the personal pronoun $I$. The use of personal pronouns is particularly important in academic writing because it determines the writer's perspective and attitude toward the readership. This study investigates the extent to which Japanese EFL learners' use of the first-person singular $I$ in essays is different from the norms of native speakers. By using subcorpora of the International Corpus of Learner English and the Louvain Corpus of Native English Essays, the study compares the use of I in argumentative essays. The results indicate that Japanese EFL learners use $I$ in a similar way to American students, but they overuse I in essays: Almost all essays by Japanese learners contain $I$ and the number of $I$ 's are excessive. The analysis also uncovers an excessive use of the phrase I think in their essays.

日本人英語学習者のアカデミックライティングにおける問題点のひとつとして主語のI の多用がある。本稿は、約20万語から成るICLE書き言葉コーパスを利用し、議論形式のア カデミックエッセーにおいて、日本人英語学習者の主語Iをどのように使用しているのか調 査し、これをアメリカとイギリスの大学生が書いたアカデミックエッセーから構成された LOCNESS書き言葉コーパスのデータと比較した。結果、日本人学生の人称代名詞のIの使用 方法はアメリカ人学生のそれに類似していたが、全体的な過剩使用が確認された。特に、 ほぼすべての学生がIを使用し、その量も過剩であった。I thinkというフレーズも母語話者の 書き言葉に比べて過剩であった。本稿は、この過剩使用の問題点を議論する。

JALT Journal, Vol. 34, No. 1, May 2012 
$\mathrm{T}$ he grammatical rules for personal pronouns are simple, but those governing their use in writing are rather complex. The choices between personal pronouns (first, second, and third person, as well as singular and plural) create different relationships between writers and readers. First- and second-person pronouns imply an interpersonal relationship between the author and audience, whereas third-person pronouns generate an impersonal context. Thus, the use of these personal pronouns differs according to the purpose of writing and the intended audience.

The use of personal pronouns is complex in academic writing. According to Pennycook (1994), pronouns are "complex and political words, always raising difficult issues of who is being represented" (p. 173). In addition, Kuo (1999) points out that personal pronouns name a self, selves, and others; therefore, their use determines the writer's position and attitude in academic society.

In particular, the use of the first-person pronoun $I$ in academic prose is controversial and has often been investigated. Conventionally, $I$ is considered less common in academic prose because it sounds conversational, informal, egocentric, and less objective (Biber, Johansson, Leech, Conrad, \& Finnegan, 1999; Chafe, 1982; Korhonen \& Kusch, 1989; Kuo, 1999; Smith, 1986). However, some studies on personal pronouns in written discourse have discussed views that $I$ is sometimes acceptable depending on the occasion and the manner in which it is used (Smith, 1986; Tang \& John, 1999), as well as on preferences of the individual and academic discipline (Coniam, 2004; Hyland, 2001; Petch-Tyson, 1998; Smith, 1986).

Accordingly, textbooks and guidebooks for academic writing treat the use of the first-person pronoun $I$ with caution. Basically, the first-person singular is not common in academic writing (Fowler \& Aaron, 2010; Johns, 1997; Langan, 2000), but some textbooks point out that it has been becoming more common in recent years in certain appropriate parts of an essay (Cooley \& Lewkowicz, 2003; Fowler \& Aaron, 2010). Nevertheless, the use of first-person singular in academic writing still greatly depends on the discipline (Bergmann, 2010; Fowler \& Aaron, 2010), and thus students are recommended to ask university supervisors whether or not the use of $I$ is accepted in their course of study (Creme \& Lea, 2008).

Academic essays by nonnative speakers have been reported as lacking balance and having greater subjectivity (Hinkel, 1999). Some corpus-based research on English academic essays written by Finnish and Swedish (Herriman \& Aronsson, 2009; Petch-Tyson, 1998) as well as Japanese (Akahori, 2007; Ishikawa, 2008) EFL learners has found an overuse of first-person 
pronouns. Some researchers have also noted that $I$ think is excessively used in essays by EFL learners from Japan (Ishikawa, 2008; Oi, 1999a), from France (Aijmer, 2002), and from several other European countries (Ringbom, 1998). When EFL learners exhibit problems in their use of personal pronouns in essays, investigating how their personal pronoun use differs from the norms of native speakers can help teachers instruct their students on how to improve their academic writing.

\section{First-Person Pronouns and Essays by Japanese EFL Learners}

One of the issues that Japanese EFL learners face in academic writing is the appropriate use of first-person pronoun singular $I$. Some instructors and researchers report that Japanese EFL learners use $I$ very frequently. In their instructional textbook for Japanese EFL learners on how to write English academic essays, Kamimura and Oi (2004) note that Japanese EFL learners use $I$ too frequently, which can make their writing lack objectivity and generality.

There are some small-scale reports on the use of $I$ in academic writing by Japanese EFL learners. Oi (1999a) compared an academic composition by an American university student with those of two Japanese university students, all of which were on the same topic. She pointed out that, unlike the American student, the Japanese students frequently used $I$ and wrote openly about their personal lives. Suganuma (2004) conducted a classroom investigation into the writing of 44 Japanese university students. Her analysis of their persuasive essays reveals that all students regularly used first-person pronouns, including I, my, me, and myself, mainly in two ways: expressing opinions and describing experiences.

An investigation into the use of personal pronouns (Akahori, 2007) also discovered the excessive use of $I$ in argumentative essays by Japanese EFL learners. The essays were written by Japanese undergraduate and postgraduate students, and were collected as part of learner corpora in the International Corpus of Learner English (ICLE). The first version of the ICLE was published in 2002, but a Japanese subcorpus was not included because the essays then written by Japanese EFL learners were not fully argumentative. Akahori compares Japanese students' writings for ICLE with those of American and British university students in the Louvain Corpus of Native English Essays (LOCNESS). Her analysis indicates that one of the reasons Japanese EFL learners' writings lack argumentativeness may be their subjective perspectives, which is seen in excessive use of I (Akahori, 2007, p. 5). 
Another corpus-based study (Ishikawa, 2008) investigated frequent words and phrases in opinion essays using the Corpus of English Essays Written by Japanese University Students (CEEJUS), finding that the personal pronouns $I$ and we, as well as the phrase I think, are very frequently used.

This study attempts a more detailed and wider scale investigation into the use of $I$ in argumentative essays by Japanese EFL learners, drawing on ICLE version 2 (ICLEv2; Granger, Dagneaux, Meunier, \& Paguot, 2009), which includes written English data produced by Japanese undergraduate and postgraduate students as a Japanese EFL subcorpus. Building on the investigations into the frequency of $I$ that have been conducted in previous reports and studies, this study will explore how the use of $I$ in argumentative essays by Japanese EFL learners is different from native speaker norms.

\section{Method}

\section{Data}

The data of Japanese EFL learners' written language used in this study comes from ICLEv2 (Granger, et al., 2009). ICLEv2 includes argumentative essays of a higher English proficiency level written by EFL learners of 16 different first-language backgrounds, who come from all over the world. The Japanese subcorpus consists of 366 argumentative essays written by Japanese undergraduate and postgraduate students, all of whom were native speakers of Japanese. The total number of words is 198,241.

The two sets of data of native speakers' written language come from LOCNESS, which comprises British pupil A-level essays, British university student essays, and American university student essays (Granger \& De Cock, n.d.). Data of argumentative essays written by university students were extracted from LOCNESS for comparison with Japanese university student argumentative essays. There were 33 argumentative essays by British university students, amounting to 19,019 words, and 175 by American students, amounting to 149,574 words. Each essay in ICLEv2 and LOCNESS was written by a different student. Table 1 shows the description of subcorpora: ICLEv2 Japanese, LOCNESS British, and LOCNESS American.

Essays in ICLEv2 and LOCNESS cover a wide range of topics. Some of the most frequent topics in ICLEv2 are English education, technology, human rights, and social issues such as environment, crime, and gender. Similarly, essays by American students in LOCNESS include a variety of issues such as euthanasia, capital punishment, and animal testing. The 33 argumentative 
essays by British students in LOCNESS, on the other hand, are on a single topic: "A single Europe: A loss of sovereignty for Britain."

Table 1. Description of the Subcorpora

\begin{tabular}{lcccc}
\hline Subcorpus & $\begin{array}{c}\text { Number of } \\
\text { essays }\end{array}$ & $\begin{array}{c}\text { Number of } \\
\text { words }\end{array}$ & $\begin{array}{c}\text { Number of } \\
\text { running words } \\
\text { with AntConc }\end{array}$ & $\begin{array}{c}\text { Mean number of } \\
\text { words per essay }\end{array}$ \\
\hline $\begin{array}{l}\text { ICLEv2 } \\
\text { Japanese }\end{array}$ & 366 & 198,241 & 202,099 & 552 \\
$\begin{array}{l}\text { LOCNESS } \\
\text { British }\end{array}$ & 33 & 19,019 & 19,042 & 577 \\
$\begin{array}{l}\text { LOCNESS } \\
\text { American }\end{array}$ & 175 & 149,574 & 150,544 & 860 \\
\hline
\end{tabular}

\section{Analysis}

This study investigates the frequency of $I$ and how $I$ is used (i.e., functions of $I$ ) in argumentative essays. The frequency of $I$ was analyzed using a concordance tool called AntConc (3.2.1w; Anthony, 2007). Three sets of comparison were made in order to examine to what extent the frequency of $I$ in academic essays varied among three corpus groups: the occurrences of $I$ per 1000 words, the number of essays including $I$, and the number of essays that overuse $I$. The datum line of overuse was determined by cluster analysis using SPSS version 15, where data of native speakers were divided into two groups according to the number of occurrences of $I$ per 1000 words. In this study, the number of essays overusing $I$ is equivalent to the number of writers who overuse I since, in ICLEv2 and LOCNESS databases, one author writes only one essay.

Although the frequency was determined automatically by the concordance tool, the functions of $I$ were analyzed manually. In this study, $I$ is classified into four categories to analyze its occurrences in context. (Note: Errors in learners' writings have not been corrected in ICLEv2.)

\section{(1) I for Personal Matters}

This feature includes I used for descriptions of the author's personal matters, such as personal identity and experience. Writers often use $I$ to write about their personal status, ability, and situation. 
I am a 21 year old male. (ICLE-US-IND-0018.1)

Instances of $I$ for expressing the writer's personal experiences and actions in the present or past are also included in this category as personal matters.

I entered university. (ICLE-JP-TM-0007.1)

I send her an email what I want to say. (ICLE-JP-SWU-0005.4)

Writers write about their feelings, hopes, and knowledge in their life.

I know a boy. (ICLE-JP-WA-0005.1)

I hope my dream come true. (ICLE-JP-SWU-0014.4)

These cases are included in this category, but the writer's feelings and hopes regarding the issue in the argumentative essays are classified into category (2), which is when $I$ is used to write about personal opinions and feelings about an issue in question.

\section{(2) I for Opinions}

The second category includes the writer's use of $I$ to argue an opinion or indicate feelings on an issue.

I think the effect is far more damaging ... (ICLE-BR-SUR-0015.3)

\section{(3) I for Organizing}

In this category, $I$ is used in the context of the organizational structure of the essay or to guide readers. The use of $I$ explicitly shows the organization and structure of the essay. It also draws attention to important points and guides readers from one point to another throughout the essay.

I am going to write about good points of both ... (ICLE-JPRI-0002.1)

(4) I Used in Conversation

The final category of $I$ is seen in direct conversational quotations.

“Yes, I am.” (ICLE-JP-SWU-0019.4) 


\section{Results}

\section{The Frequency}

Frequency analysis shows that $I$ occurs about five to ten times more often in Japanese EFL learners' essays than in native speaker essays. When the frequency is measured as the number of occurrences per 1000 words (Table 2 ), it is found that Japanese EFL learners use I 21.15 times per 1000 words, whereas British and American students use I 2.83 and 4.44 times per 1000 words, respectively.

The analysis of the number of essays including $I$ also shows that most argumentative essays written by Japanese EFL learners include $I$. Out of the 366 essays they authored, 95.90\% (351) include $I$. On the other hand, $54.55 \%$ and $58.86 \%$ of British and American student essays, respectively, contain $I$.

\section{Table 2. Instances of I in Essays by Japanese, British, and American Students}

\begin{tabular}{lccc}
\hline & $\begin{array}{c}\text { ICLEv2 } \\
\text { Japanese }\end{array}$ & $\begin{array}{c}\text { LOCNESS } \\
\text { British }\end{array}$ & $\begin{array}{c}\text { LOCNESS } \\
\text { US }\end{array}$ \\
\hline Number of essays & 366 & 33 & 175 \\
Instances of $I$ & 4275 & 54 & 668 \\
Maximum number of $I$ in an essay & 73 & 12 & 32 \\
Minimum number of $I$ in an essay & 0 & 0 & 0 \\
Standard deviation & 11.21 & 2.53 & 6.02 \\
Instances of $I$ (per 1000 words) & 21.15 & 2.83 & 4.44 \\
Number of essays including $I$ & 351 & 18 & 103 \\
& $(95.90 \%)$ & $(55.55 \%)$ & $(58.86 \%)$ \\
Mean of $I$ per essay & 11.68 & 1.64 & 3.82 \\
\hline
\end{tabular}

Looking at the individual data, I found that some students use I more excessively than others. On the basis of cluster analysis, both the British and the American data were divided into two groups, depending on whether or not the data included $I$ seven times or more per 1000 words. Since the average number of occurrences of $I$ per 1000 words in British and American data were 2.83 and 4.44 respectively, it seemed reasonable to choose seven or more occurrences of $I$ per 1000 words as the criterion for overuse. 
Such excessive users of $I$ are a minority of native speakers, but a majority of Japanese. In the American data, 39 essays out of 175 (22.29\%) showed an overuse of $I$. In the British data, five essays (15.15\%) showed overuse. Most instances of $I$ occurred in the work of a limited number of excessive users. In the American data, $75.30 \%$ of $I$ use is in $22.29 \%$ of essays, and in the British data, $59.26 \%$ of $I$ use is in $15.15 \%$ of essays.

On the other hand, in the Japanese data, 284 of 366 essays (77.60\%) showed an overuse of $I$. The number of students who did not overuse $I$ was 82 (22.40\%), including those who did not even use $I$ at all (15). Approximately $96 \%$ of Japanese learners used $I$ in their essays, and nearly $80 \%$ overused it.

\section{Different Uses in Context}

The functions of $I$ in essays was analyzed to discover how $I$ is used (Table 3 ). Approximately $60 \%$ of $I$ was used for writing about the writers' personal matters in the American and Japanese essays, but this was rarely seen in the British essays (11.11\%). Japanese and American essays were also similar in the use of $I$ to convey the author's opinions $(32.0 \%$ and $27.99 \%$, respectively) and in conversational quotations (1.43\% and $1.95 \%$, respectively). On the other hand, the British students mainly used $I$ when they wrote about their opinions: $77.78 \%$ of instances of $I$ in essays by British students were for this purpose. Direct conversational quotations were absent from the British students' essays examined here. The single similarity among Japanese, American, and British students is the usage of $I$ for organizing the essays. In each group, approximately $10 \%$ of instances of $I$ were used in this manner.

Table 3. The Purposes of Using I

\begin{tabular}{lccccc}
\hline & $\begin{array}{c}\text { Personal } \\
\text { matters }\end{array}$ & Opinions & Organization & $\begin{array}{c}\text { In } \\
\text { conversation }\end{array}$ & Total \\
\hline Japanese ICLE v2 & Total 366 / & Excessive & users 284, 77.60\%) \\
\hline Frequency & 2531 & 1368 & 314 & 62 & 4275 \\
(Excessive users) & $(2509)$ & $(1277)$ & $(290)$ & $(60)$ & $(4136)$ \\
\hline$\%$ & $59.20 \%$ & $32.0 \%$ & $7.35 \%$ & $1.45 \%$ & $100 \%$ \\
(Excessive users) & $(58.69 \%)$ & $(29.87 \%)$ & $(6.78 \%)$ & $(1.40 \%)$ & $(96.74 \%)$ \\
\hline Per 1000 words & 12.52 & 6.77 & 1.55 & 0.31 & 21.15 \\
(Excessive users) & $(16.00)$ & $(8.15)$ & $(1.85)$ & $(0.38)$ & $(26.38)$ \\
\hline
\end{tabular}




\begin{tabular}{lccccc}
\hline & $\begin{array}{c}\text { Personal } \\
\text { matters }\end{array}$ & Opinions & Organization & $\begin{array}{c}\text { In } \\
\text { conversation }\end{array}$ & Total \\
\hline British LOCNESS Total 33 / Excessive users & $5,15.15 \%)$ & & \\
\hline Frequency & 6 & 42 & 6 & 0 & 54 \\
(Excessive users) & $(6)$ & $(23)$ & $(3)$ & $(0)$ & $(32)$ \\
\hline$\%$ & $11.11 \%$ & $77.78 \%$ & $11.11 \%$ & 0 & $100 \%$ \\
(Excessive users) & $(11.11 \%)$ & $(42.59 \%)$ & $(5.56 \%)$ & $(0)$ & $(59.26 \%)$ \\
\hline Per 1000 words & 0.31 & 2.21 & 0.31 & 0 & 2.83 \\
(Excessive users) & $(2.08)$ & $(7.97)$ & $(1.04)$ & $(0)$ & $(11.09)$ \\
\hline American LOCNESS (Total 175 / Excessive users 39, 22.29\%) & \\
\hline Frequency & 397 & 187 & 71 & 13 & 668 \\
(Excessive users) & $(334)$ & $(114)$ & $(47)$ & $(8)$ & $(503)$ \\
\hline$\%$ & $59.43 \%$ & $27.99 \%$ & $10.63 \%$ & $1.95 \%$ & $100 \%$ \\
(Excessive users) & $(50 \%)$ & $(17.06 \%)$ & $(7.04 \%)$ & $(1.20 \%)$ & $(75.30 \%)$ \\
\hline Per 1000 words & 2.64 & 1.24 & 0.47 & 0.09 & 4.44 \\
(Excessive users) & $(9.96)$ & $(3.40)$ & $(1.40)$ & $(0.23)$ & $(14.99)$ \\
\hline
\end{tabular}

\section{Excessive Users of I}

Although the use of $I$ by Japanese and American students is similar in the percentages of how $I$ is used in context, the biggest difference is that the excessive use of $I$ was seen only in a limited number of essays in the native speakers' writing, while it was seen in most of the Japanese data.

The most frequent use of $I$ in American essays was for writing about personal matters, for which it was used in $44.57 \%$ of essays, but most of these instances $(84.13 \%)$ appeared in the writing of excessive users, who make up $22.29 \%$ of the American data. Likewise, the use of $I$ by excessive writers outnumbered the use of $I$ by all other writers in the other categories: $I$ for expressing opinions, showing the organization of the essay, and in conversation (Table 3).

Similarly in British essays, I was used primarily by the five excessive writers, who made up only $15.15 \%$. I for personal matters was used only in essays by these excessive writers. In particular, the overuse of $I$ in British data was limited to a single use-to express opinions-and $56.76 \%$ of $I$ for this use was seen in the excessive writers' essays.

On the other hand, $77.60 \%$ of the Japanese students were excessive users of $I$. Overall, more than $90 \%$ of $I$ for each type of use was accounted for by the excessive users. 


\section{Excessive Use of I Think}

Further investigation uncovered the excessive use of I think in essays by the Japanese EFL learners. As Table 4 displays, think was the most frequent word to collocate with $I$ in Japanese essays. I co-occurs with think 4.30 times per 1000 words, which account for $20 \%$ of the total occurrences of $I$. The Japanese learners over-depended on using I think. In essays by native speakers, on the other hand, think was a frequent word associated with $I$, but other verbs that made up phrases used to show the author's "stance" (Biber et al., 1999), such as feel and believe, were also used (see Table 4).

\section{Table 4. Words That Collocate With I (Immediately Preceding or Following)}

\begin{tabular}{rcccccc}
\hline \multirow{2}{*}{ 藏 } & \multicolumn{2}{c}{ ICLEv2 Japanese } & \multicolumn{2}{c}{ LOCNESS British } & \multicolumn{2}{c}{ LOCNESS American } \\
\cline { 2 - 6 } & Frequency* & Collocate & Frequency* & Collocate & Frequency* & Collocate \\
\hline 1 & $867(4.30)$ & think & $10(0.53)$ & feel & $62(0.41)$ & have \\
2 & $214(1.06)$ & don't & $6(0.32)$ & think & $42(0.28)$ & feel \\
3 & $206(1.02)$ & want & $5(0.26)$ & would & $41(0.27)$ & think \\
4 & $195(0.96)$ & can & $5(0.26)$ & believe & $37(0.25)$ & was \\
5 & $182(0.90)$ & was & $4(0.21)$ & am & $32(0.21)$ & would \\
6 & $179(0.89)$ & am & $3(0.16)$ & have & $30(0.20)$ & 'm \\
7 & $171(0.85)$ & have & $2(0.01)$ & use & $27(0.18)$ & am \\
8 & $102(0.50)$ & will & $2(0.01)$ & can & $24(0.16)$ & know \\
9 & $82(0.41)$ & 'm & $1(0.05)$ & wouldn't & $22(0.15)$ & believe \\
10 & $75(0.37)$ & would & $1(0.05)$ & therefore & $18(0.12)$ & had \\
\hline
\end{tabular}

* per 1000 words

\section{Discussion}

The results of this wider scale corpus-based study confirm what previous studies claim: that $I$, as well as I think, is overused in essays by Japanese EFL learners (Akahori, 2007; Ishikawa, 2008; Oi, 1999a). In addition, the use of $I$ in context is found to be similar to Suganuma's (2004) results, which discovered that the first-person pronouns are mainly used for expressing opinions $(30 \%)$ and for stating the writer's personal experience $(70 \%)$. The comparison with native speakers' essays in this study revealed that $I$ appears occasionally in essays by native speakers, and that the number of 
essays in which $I$ is overused is limited, whereas $I$ is overused in most of the essays by the Japanese EFL learners.

\section{Use of I and Overuse of I}

Although native speakers of English at tertiary education institutions do not use I nearly as frequently as Japanese EFL learners do, this study reveals that some of them occasionally use it in their academic essays. The first-person pronoun $I$ appeared in $54.55 \%$ and $58.89 \%$ of essays by the British and American students, respectively. As textbooks and guidebooks for academic writing report, it is common to see the occasional use of I in students' essays.

There are, however, some differences between writing by British students and American students. Biber (1987) finds more cases of $I$ and you pronouns in American academic prose than British academic prose, and this study also found more cases of $I$ in American students' essays than British students' essays. One possible explanation given by Biber is that $I$ and you pronouns are factors indicating an interactive and colloquial style, and American writing has a "greater use (or tolerance) of informal, colloquial, and interactional features" (p. 113). In addition to the colloquial language use in American writing, this study suggests that American and British students use the personal pronoun $I$ for different purposes. Both British and American students use $I$ to express opinions, but American students in particular write about their personal matters in essays. Personal experience is considered to be acceptable in "academic composition in Anglo-American educational environments" (Hinkel, 1999, p. 91), but there might be differences in the use of $I$ even among native speakers with different cultural and educational backgrounds, as a study by Connor \& Lauer (1988) suggests.

Although the use of $I$ is for the most part acceptable, the overuse of $I$ could spoil a piece of academic writing, regardless of the writer's native language, from two points of view: (a) academic tone and (b) subjectivity. An impersonal and formal tone is preferred in professional, academic writing; overuse of $I$ may disconcert readers by making the text seem conversational, interactive, and less formal. The use of $I$ indicates the writer's involvement with the audience (Chafe, 1982), which is also referred to in several other ways, such as presence of writer (Hyland, 2001; Smith, 1986) and writer/ reader visibility (Petch-Tyson, 1998); the frequent use of $I$ is a common feature of spoken language and is therefore less formal (Smith, 1986). Investigations into academic writing confirm this: $I$ is not used in scientific articles (Kuo, 1999). In addition, Korhonen and Kusch (1989) and Kuo find that in 
many argumentative texts, the plural we is more dominant as compared to the singular $I$.

Although this study does not aim to investigate the rhetoric in writing, the quality of rhetoric can be considered partly from the use of $I$. Essays with frequent $I$, with occasional $I$, and without $I$ show some differences in their argumentation. Most essays with excessive use of $I$ argue an issue from personal experience throughout the essay; by contrast, in writing where $I$ is used only occasionally, personal experience is only one among various resources for argument. Writing about personal matters is a feature of personal writing rather than academic writing (Creme \& Lea, 2008). Writers who frequently use $I$ for expressing opinions typically discuss an issue only from their personal connection to it. Sometimes the whole essay and at other times only part of the essay is heavily argued from a subjective point of view. In essays with little or no $I$, writers usually mention several points of view, for example, for and against or pros and cons. They express their opinions indirectly but clearly by advocating or criticizing other ideas. Thus, such essays often include a detailed analysis of the issue.

\section{Japanese Learners}

It is a problem that most Japanese university students overuse $I$ in their academic writing. In other words, Japanese learners of English write academic essays in conversational, less formal, interactive, personal, and subjective tones, and in so doing may risk putting off readers from other backgrounds. Several factors are believed to account for their overuse of $I$ in academic essays, including the following: (a) Japanese language and Japanese writing culture, (b) lack of writing skills as language learners, and (c) textbooks written for EFL learners.

Investigations into the rhetoric patterns of writing in English by Japanese learners have revealed that they are influenced by the rhetoric patterns appropriate to Japanese writing (Hinds, 1983; Oi, 1999b). The overuse of $I$, resulting in too much presence of the writer in an essay, could also be influenced by the Japanese language and Japanese writing culture. It is sometimes argued that the Japanese language is a predicative-oriented language, and it is syntactically very different from Western languages (Morita, 2002). Japanese discourse is always expressed from a speaker's point of view and the speaker is not always present in the discourse, unlike English discourse, in which the speaker is always identified. Oi (1999a) and Kamimura and Oi (2001) discuss the fact that English is a subject-predicate type language, 
while the Japanese language is typologically a topic-comment type: Comments on the topic in Japanese discourse are provided from the speaker's point of view. Therefore, if Japanese students try to translate what they want to say in Japanese into English, the easiest subject for them to use is $I$.

Since Japanese discourse reflects the speaker's perspective, the typical and traditional composition written in Japanese is full of subjectivity. In school, the typical composition is based on the student's personal experience or on a topic close to the student, and consists of the details of an event and the student's personal opinions or feelings concerning it. Whereas the main aim of composition writing in American elementary schools is the development of writing skills and techniques such as essay organization, Japanese elementary schools aim at nurturing personality through expressing personal experiences and feelings (Watanabe, 2004). Such traditional composition writing in Japan influences the English writing skills of Japanese learners (Oi, 1999a; Suganuma, 2004).

Japanese learners' excessive use of the subjective phrase I think to express opinions is also likely influenced by the Japanese language (I think $=o m o u$ ). The main definitions of I think and omou are similar to each other. In Japanese omou is used to show opinions as well as uncertainty (Moriyama, 1992). While omou can also be translated as one may think or it is thought, virtually all writers, using I, apply it by default as the subject of think. Similarly, in English, I think is "used when you are saying that you believe something is true, although you are not sure" (Longman Dictionary of Contemporary English, 2003, p. 2014). Such similarities must make it easy for Japanese EFL learners to say I think.

Another reason for the excessive use of I think can be explained from the rhetoric pattern of English written by Japanese students. According to rhetoric studies, Japanese learners tend not to assertively express their opinions. Kamimura and Oi (1998) argue that Japanese students excessively use I think as a softening device, while American students occasionally use I think as an emphatic device. In their study, 80\% of Japanese learners used I think before stating their opinions. Oi (1999b) discovered that Japanese learners use indecisive argumentation in their essays. They write their thinking process in essays. They use I think to show opinions along with their thinking process, resulting in indecisive argumentation. The overuse of I think reflects a direct translation from omou and the indecisive manner of writing in the Japanese language and culture.

The overuse of $I$ and a subjective tone are not limited to writing by Japanese EFL learners; they also appear in the writing of EFL learners from 
various other first-language backgrounds. Hvitfeldt (1992) finds that the writing of many Malay students is personalized and includes descriptions of their personal lives. She explains that personalization is commonly seen in writing from oral-oriented cultures, yet she also argues that the same feature is found in writing by "students who have not yet made the shift from the oral discourse style to the more literate discourse style" (p. 38), regardless of their native language. The shift is likewise depicted in Ivanič and Camps (2001); a Mexican student shifted from her preference for using first person to the use of an impersonal style of writing accepted by academics. Furthermore, a series of studies that investigated the learners' written language using ICLE corpus data found a higher frequency of language use that shows writer or reader visibility (Petch-Tyson, 1998) and a higher frequency of the subjective phrase I think in writings by European EFL learners (Aijmer, 2002; Herriman \& Aronsson, 2009; Ringbom, 1998), which leads the researchers to conclude that this reflects the trait of a conversational tone in learners' writing. According to Biber et al. (1999) and Biber and Reppen (1998), the phrase, I think as well as I think that are typically spoken phrases, and they are rarely seen in academic prose. Finally, the overuse of $I$ can be explained from the simple structural repertoire of EFL learners. As seen in Table 4, the be-verb often co-occurs with $I$ in Japanese learners' writing, which reflects the over-statement of personal matters in their compositions. This be-copula as a feature of simple syntax is commonly seen in writings by nonnative speakers (Hinkel, 2003). The overuse of $I$ and $I$ think observed in EFL learners shows that they are in the process of language learning.

Finally, the influence of textbooks and instructions for writing at the tertiary level in Japan should be considered. There are many textbooks that provide ample writing exercises and model essays where the writer's life and opinions are at the center of the description. Textbooks emphasizing "the cognitive process of writing" often focus on the students' personal experiences and interests as a topic (Spack, 1988). In addition, personalexpressivist and learner-centered views (Johns, 1997), whose focus is to develop students' fluency and confidence in writing, encourage students to write about personal experiences and thoughts. Such practices are common in textbooks used in EFL classrooms, but it is questioned whether such personal writing exercises actually help students to develop the academic writing skills required outside language lessons (Johns, 1997; Spack, 1988). A background full of personal writing could affect the writer's choice of the first person in his or her academic writing. 


\section{Conclusion}

This study investigates the details of the overuse of $I$ in argumentative essays written by Japanese EFL learners using the Japanese subcorpus in ICLEv2. Most Japanese learners overuse $I$ in English academic essays. They particularly overuse $I$ to write about personal matters and to express their opinions. In order to show their opinions, the phrase I think is excessively used. The findings imply that the overuse of $I$ in essays by Japanese EFL learners is influenced by their linguistic and cultural background as well as lack of academic writing skills. Although the use of personal pronouns is a small factor in academic writing, teaching how to use them will help improve the EFL learners' academic writing in terms of objectivity, maintaining an impersonal perspective, and formality.

One of the limitations in this study is that the sizes of the subcorpora are not equal; in particular, the amount of corpus data from British university students is smaller than the amounts from Japanese and American students. Therefore, diversity between American and British students is not conclusive. Nonetheless, the investigation into the three subcorpora provides informative implications for teaching.

The findings should be taken into account when English academic writing instruction is given to Japanese EFL learners, especially at the university level. First, teachers should help students develop their overall academic writing skills. For example, students may know the grammatical rules for personal pronouns but not necessarily be aware of the appropriateness of their usage or the perspectives that they connote. Both linguistic correctness and appropriateness for the context are important in academic writing. In addition, teachers can raise students' awareness of differences between English academic writing and Japanese techniques that they have learned before entering university. Additionally, in teaching rhetoric or argumentation in English at the micro-level, teachers should help students learn how to use a wider variety of linguistic expressions to enable them to write opinions and show organization of an essay both with and without $I$. Last but not least, textbooks for EFL courses and language input from reading should be selected more carefully.

\section{Note}

The original version of this paper was presented at JALT2010 in Nagoya, Aichi (Natsukari, 2010). 
Sayo Natsukari is currently an adjunct lecturer at Rikkyo University.

\section{References}

Akahori, N. (2007). The excessive use of the first-person pronoun "I" in English compositions by Japanese students. Nihonjin eigo gakushusha no hanashikotoba kakikotoba no corpus sakusei to sono goyoron teki taishobunseki [Building learner corpora of Japanese learners of English and the contrastive analyses]. (Report for Grant-in-Aid for Scientific Research (B) No. 15320059). Tokyo: Brainsnetwork.

Aijmer, K. (2002). Modality in advanced Swedish learners' written interlanguage. In S. Grenger, J. Hung, \& S. Petch-Tyson (Eds.), Computer learner corpora, second language acquisition and foreign language teaching (pp. 55-76). Amsterdam: John Benjamins.

Anthony, L. (2007). AntConc (Version 3.2.1w) [Computer Software]. Tokyo, Japan: Waseda University. Available from http://www.antlab.sci.waseda.ac.jp/

Bergmann, L. S. (2010). Academic research and writing. Boston: Longman.

Biber, D. (1987). A textual comparison of British and American writing. American Speech, 62(2): 99-119.

Biber, D., Johansson, S., Leech, G., Conrad, S., \& Finnegan, E. (1999). Longman grammar of spoken and written English. London: Pearson Longman.

Biber, D. \& Reppen, R. (1998). Comparing native and learner perspectives on English grammar: A study of complement clauses. In S. Granger (Ed.), Learner English on computer (pp. 145-158). New York: Longman.

Chafe, W. L. (1982). Integration and involvement in speaking, writing, and oral literature. In D. Tannen (Ed.), Spoken and written language: Exploring orality and literacy (pp. 35-53). Norwood, NJ: Ablex.

Coniam, D. (2004). Concordancing yourself: A personal exploration of academic writing. Language Awareness, 13, 49-55.

Connor, U., \& Lauer, L. (1988). Cross-cultural variation in persuasive student writing. In A. C. Purves (Ed.), Writing across languages and cultures (pp. 138-159). Newbury Park, CA: Sage.

Cooley, L., \& Lewkowicz, J. (2003). Writing at university: A guide for students (3rd ed.). Maidenhead, UK: Open University Press.

Creme, P., \& Lea, M. R. (2008). Writing at university (3rd ed.). New York: McGraw-Hill.

Fowler, H. R., \& Aaron, J. E. (2010). The little, brown handbook (11th ed.). New York: Pearson Education. 
Granger, S., Dagneaux, E., Meunier, F., \& Paguot, M. (2009). International corpus of learner English version 2. Louvain-la-Neuve, Belgium: Presses Universitaires de Louvain.

Granger, S., \& De Cock, S. (n.d.). LOCNESS: Louvain corpus of native English essays. Retrieved from http://www.uclouvain.be/en-cecl-locness.html

Herriman, J., \& Aronsson, M. B. (2009). Themes in Swedish advanced learners' writing in English. In K. Aijmer (Ed.), Corpora and language teaching (pp. 101-120). Amsterdam: John Benjamins.

Hinds, J. (1983). Contrastive rhetoric: Japanese and English. Text, 3, 183-195.

Hinkel, E. (1999). Objectivity and credibility in L1 and L2 academic writing. In E. Hinkel (Ed.), Culture in second language teaching and learning (pp. 90-108). Cambridge: Cambridge University Press.

Hinkel, E. (2003). Simplicity without elegance: Features of sentences in L1 and L2 academic texts. TESOL Quarterly, 37, 275-301.

Hvitfeldt, C. (1992). Oral orientations in ESL academic writing. College ESL, 2(1), 2939.

Hyland, K. (2001). Humble servants of the discipline? Self-mention in research articles. English for Specific Purposes, 20, 207-226.

Ishikawa, S. (2008). Eigo corpus to gengo kyoiku [English corpus and language education]. Tokyo: Taishukan.

Ivanič, R., \& Camps, D. (2001). I am how I sound: Voice as self-representation in L2 writing. Journal of Second Language Writing, 10, 3-33.

Johns, A. M. (1997). Text, role, and context. Cambridge: Cambridge University Press.

Kamimura, T., \& Oi, K. (1998). Argumentative strategies in American and Japanese English. World Englishes, 17, 307-323.

Kamimura, T., \& Oi, K. (2001). The effects of differences in point of view on the story production of Japanese EFL students. Foreign Language Annals, 34, 118-130.

Kamimura, T., \& Oi, K. (2004). Eigo rombun, report no kakikata [How to write essays and reports in English]. Tokyo: Kenkyusha.

Korhonen, R., \& Kusch, M. (1989). The rhetorical function of the first person in philosophical texts-The influence of intellectual style, paradigm and language. In M. Kusch \& H. Schröder (Eds.), Text, interpretation, argumentation (pp. 61-77). Hamburg: Helmut Buske.

Kuo, C.-H. (1999). The use of personal pronouns: Role relationships in scientific journal articles. English for Specific Purposes, 18, 121-138.

Langan, J. (2000). College writing skills (5th ed.). Singapore: McGraw-Hill. 
Longman dictionary of contemporary English (4th ed.). (2003). Harlow, UK: Longman. Morita, Y. (2002). Nihongo bunpo no hassou [A conception of Japanese grammar]. Tokyo: Hitsuji Shobo.

Moriyama, T. (1992). Bunmatsu shiko doshi "omou" wo megutte [On mental verb, omou]. Nihongogaku [Japanese Studies], 11(9), 105-116.

Natsukari, S. (2010, November). The use of I ofJapanese EFL learners. Paper presented at the Conference of the Japan Association for Language Teaching, Nagoya, Japan.

Oi, K. (1999a). A note on Japanese students' preference for the first person perspective in writing in English. Monograph Series, 37-47.

Oi, K. (1999b). Comparison of argumentative styles: Japanese college students vs. American college students-An analysis using the Toulmin model. JACET Bulletin, 30, 85-102. Retrieved from NII-Electronic Library Service.

Petch-Tyson, S. (1998). Writer/reader visibility in EFL written discourse. In S. Granger (Ed.), Learner English on computer (pp. 107-118). New York: Longman.

Pennycook, A. (1994). The politics of pronouns. ELT Journal, 48, 173-178.

Ringbom, H. (1998). Vocabulary frequencies in advanced learner English: A crosslinguistic approach. In S. Granger (Ed.), Learner English on computer (pp. 41-52). New York: Longman.

Smith, Jr., E. L. (1986). Achieving impact through the interpersonal component. In B. Couture (Ed.), Functional approaches to writing: Research perspectives (pp. 108119). London: F. Pinter.

Spack, R. (1988). Initiating ESL students into the academic discourse community: How far should we go? TESOL Quarterly, 22, 29-51.

Suganuma, A. (2004). Persuasive writing in English by Japanese EFL learners: A study on their frequent use of first person singular pronouns. The Society of English Studies, 34, 21-34. Retrieved from NII-Electronic Library Service.

Tang, R., \& John, S. (1999). The 'I' in identity: Exploring writing identity in student academic writing through the first-person pronoun. English for Specific Purposes, 18, S23-S39.

Watanabe, M. (2004). Nattoku no kozo [Structure of convincement]. Tokyo: Toyokan. 